\title{
DINAMIKA DAERAH PENANGKAPAN IKAN PELAGIS DI KOTA AMBON
}

\author{
Hansje Matakupan ${ }^{1 *}$, J Hiariey ${ }^{2}$, A. Tupamahu ${ }^{3}$, dan M. S. Baskoro ${ }^{4}$ \\ ${ }^{1}$ PS PSP FPIK, Universitas Pattimura, Ambon, \\ ${ }^{2}$ PS AGP FPIK, Universitas Pattimura, Ambon \\ ${ }^{3}$ PS PSP FPIK, Universitas Pattimura, Ambon, \\ ${ }^{4}$ PS PSP IPB, Bogor \\ e-mail korespondensi: hans_eline@yahoo.com
}

\begin{abstract}
Abstrak
Perairan Kota Ambon dan sekitarnya dimanfaatkan oleh nelayan sebagai daerah penangkapan ikan (DPI) pelagis. Aktifitas pemanfaatannya terindikasi dinamis sebab terjadi perubahan dan perkembangan penerapan teknologi penangkapan ikan serta peraturan di bidang perikanan. Penelitian dilakukan dengan tujuan memetakan batas dan menentukan luas daerah penangkapan ikan, mengetahui aksesibilitas, produksi, daerah dan musim penangkapan ikan pelagis, serta mengetahui permasalahan dan konflik pemanfaatan daerah penangkapan ikan pelagis. Data lapangan dikumpulkan pada lokasi terpilih dengan metode RRA dan PRA, juga dengan menggunakan kuesioner serta data sekunder dari berbagai sumber terpercaya. Analisis data dilakukan dengan bantuan komputer, yakni pemetaan batas dan penentuan luas DPI dengan metode kartometrik. Musim penangkapan ikan dianalisis dengan pendekatan statistik serta dibahas secara deskriptif. Permasalahan dan konflik pemanfaatan DPI dibuat dalam tabel untuk dibahas. Hasil pemetaan batas dan penentuan luas DPI Kota Ambon seluas 419,97 $\mathrm{km}^{2}$ dan nelayan Kota Ambon dapat mengakses DPI hingga seluas $1.316,46 \mathrm{~km}^{2}$ bahkan lebih luas lagi pada perairan sekitarnya Pada umumnya puncak musim penangkapan ikan pelagis di DPI Kota Ambon terjadi pada musim pancaroba II hingga musim Barat dan paceklik pada musim Timur.
\end{abstract}

Kata kunci: Dinamika, Daerah Penangkapan, Ikan Pelagis, Kota Ambon

\section{DYNAMICS OF PELAGIC FISH FISHING GROUND IN AMBON CITY}

\begin{abstract}
The waters of Ambon City and its surroundings are used by fishermen as a pelagic fish fishing ground (FG). The utilization activity is indicated dynamic because there are changes and developments in the application of fishing technology and fisheries regulations. The study was conducted with the aim of mapping the boundary and determining the largeness of fishing area, knowing the accessibility, the production, the area and the pelagic fishing season, and knowing the problems and conflict of utilization of pelagic fish fishing area. Field data collected at selected sites with RRA and PRA methods, also using questionnaires as well as secondary data from various reliable sources. Data analysis was done with computer aid, ie boundary mapping and determination of FG area largeness with cartometric method. Fishing seasons were analyzed by statistical approach and discussed descriptively. Problems and conflicts of FG utilization are made in the table to discussed. The result of boundary mapping and determination of area of FG of Ambon City is 419,97 $\mathrm{km}^{2}$ and Ambon City fishermen can access FG up to the area of $1,316,46 \mathrm{~km}^{2}$ even wider in the surrounding waters. In general, the peak of pelagic fish fishing season in Ambon city's FG occurs in transition period II season to West season and famine in East season.
\end{abstract}

Key Words: Dynamics, Fishing Ground, Pelagic Fish, Ambon City

\section{PENDAHULUAN}

Sumberdaya perikanan yang tersedia di daerah penangkapan ikan (fishing ground), pada dasarnya bersifat akses terbuka (open acces) sehingga setiap orang dapat memanfaatkan atau mengeksploitasinya dan merupakan milik bersama (common property) dimana individu atau kelompok memiliki klaim atas sumberdaya yang dikelola bersama (Fauzi, 2010). Kondisi ini bila tidak dikelola dengan baik, setidaknya dapat menyebabkan tiga keadaan yaitu: (1) laju hasil tangkapan yang rendah, (2) pendapatan rendah, dan (3) akumulasi modal secara berlebihan dalam industri perikanan (Widodo dan Suadi, 2006).

Pengelolaan suatu perairan sebagai daerah penangkapan ikan (DPI) yang baik, memerlukan kondisi dan kriteria pemilihan yang tepat. Kondisi perairan yang memadai dan dibutuhkan untuk membentuk daerah penangkapan ikan yang baik, setidaknya harus memenuhi persyaratan sebagai berikut: 1) Perairan tersebut harus memiliki kondisi dimana ikan datang dengan mudah secara bersamasama dalam bentuk kelompok, dan daerah itu merupakan suatu tempat yang baik bagi habitat mereka, 2) Perairan tersebut akan menjadi tempat dimana nelayan dengan mudah mengoperasikan alat penangkapan ikan, dan 3) Perairan tersebut akan dilokasikan sebagai suatu tempat yang bernilai ekonomis. Eksistensi suatu perairan yang dijadikan sebagai daerah penangkapan ikan dapat diketahui menurut jenis dan musim penangkapan ikan. Pemilihan daerah penangkapan akan dibuat dengan pengertian yang pantas secara efisien, menyenangkan dan penangkapannya bernilai ekonomi.

Kota Ambon berada di Pulau Ambon yang secara ekologis memiliki karakteristik kondisi pulau 
kecil dan biasanya homogen, sehingga pemanfaatan sumberdayanya dapat berifat multiple use terutama di wilayah tropis. Sumberdaya pulau-pulau kecil dapat saja dimanfaatkan untuk berbagai aktifitas ekonomi, misalnya pariwisata, perikanan tangkap, perikanan budidaya, dan lain-lain, secara bersamaan atau bergantian, sesuai kondisi alamnya. Pemanfaatan muliple use ini, pada dasarnya juga menyimpan permasalahan yang cukup pelik dan menimbulkan konflik cukup serius, mengingat keterbatassan pulaupulau kecil dimaksud (Fauzi dan Anna, 2005). Pemanfaatan dan pengelolaan sumberdaya di wilayah perairan Kota Ambon yang teridentifikasi yaitu sebagai DPI berupa aktivitas penangkapan ikan pada perikanan tangkap, perikanan budidaya, pariwisata, dan alur pelayaran.

Pemanfaatan perairan Kota Ambon oleh nelayan sebagai DPI perlu diteliti sebab aktifitasnya berlangsung sangat dinamis, terutama sebagai akibat adanya penerapan teknologi penangkapan ikan oleh nelayan, perubahan kondisi lingkungan perairan, dan perubahan peraturan perundangan serta kebijakan yang terkait dengan perikanan tangkap terkini. Perubahan kondisi lingkungan perairan di DPI yang berdampak pada musim penangkapan ikan, juga merupakan penentu aktivitas nelayan untuk menghasilkan produksi ikan dengan optimal.

Dengan demikian perlu dilakukan penelitian mengenai pemetaan batas dan menentukan luas DPI di perairan Kota Ambon dan sekitarnya dan menentukan musim penangkapan ikan pelagis. Hasil penelitian ini dapat memberikan informasi ilmiah untuk memanfaatkan dan mengelola sumberdaya perikanan di DPI Kota Ambon dan sekitarnya dengan tepat dan baik.

\section{METODE PENELITIAN}

\section{Pengumpulan Data}

Penelitian ini dilaksanakan di Kota Ambon dari bulan Januari hingga bulan Desember 2017 dan pemilihan lokasi survei mengacu pada Wilayah Administratif Pemerintahan Kota Ambon, serta ketersediaan data dan informasi daerah penangkapan ikan dan statistik perikanan tangkap pelagis skala kecil. Data produksi, musim, dan lokasi penangkapan ikan pelagis bersumber dari Dinas Kelautan dan Perikanan, Badan Pusat Statistik dan rujukan pendataan langsung di lokasi penelitian. Aktivitas operasi penangkapan ikan oleh nelayan Kota Ambon bulanan sepanjang tahun, mencakup musim dan lokasi penangkapan ikan pelagis, serta permasalahan dan konflik pemanfaatan daerah penangkapan ikan, diperoleh melalui rekaman data hasil survey dengan metode Rapid Rural Appraisal (RRA) dan Participation Rural Appraisal (PRA) (DKP, 2006; Freudenberger, 2008), dilengkapi daftar pertanyaan (kuesioner) tertutup maupun terbuka dari 170 (seratus tujuh puluh responden pada 16 (enam belas) lokasi penelitian di Kota Ambon.

Pengumpulan data dan informasi sekunder lainnya diperoleh dari berbagai sumber pustaka terkini yang dipublikasikan secara tertanggungjawab, berkaitan dengan peraturan perundangan, dan kebijakan pembangunan di Kota Ambon. Data iklim dan cuaca diperoleh dari Badan Pusat Statistik (BPS) Kota Ambon dan Badan Meteorologi Klimatologi Dan Geofisika (BMKG) Stasiun Meteorologi Pattimura Ambon.

\section{Analisis Data}

Penentuan batas dan luas daerah penangkapan ikan (DPI) di perairan Kota Ambon dan sekitarnya, dianalisis dengan teknik digitasi melalui pendekatan Sistem Informasi Geografis (SIG), menggunakan metode kartometrik berdasarkan hasil interpretasi data citra digital Lansat ETM 7+ dan peta dasar (base map) Kota Ambon. Pemetaan DPI Kota Ambon dilakukan dengan bantuan software MapInfo 10 dan ArcView 10.

Berbagai data dan informasi sekunder lainnya, juga dipergunakan untuk mendukung penentuan batas wilayah pengelolaan laut terkait dengan pemanfaatan perairan Kota Ambon sebagai daerah penangkapan ikan pelagis.

Daerah dan musim penangkapan ikan pelagis di perairan Kota Ambon dan sekitarnya, diperhitungkan dan dibahas secara deskriptif. Pola pembagian sub daerah penangkapan ikan (sub DPI), mengikuti pembagian DPI yang digunakan oleh Kawaguci et all (2006). Penentuan pola musim penangkapan ikan pelagis di berbagai sub DPI berdasarkan Indeks Musim (IM) dengan menggunakan metode analisis runtun waktu (times series analysis) menurut Spiegel, M. R., (1961) dalam Kekenusa (2006). Prosedur analisis secara matematis sebagai berikut:

1) Penentuan keberhasilan penangkapan ikan pelagis dinilai berdasarkan hasil tangkapan per unit usaha atau Catch per Unit of Effort (CPUE) yang merupakan indeks kelimpahan ikan (DKP, 2004). Perhitungan CPUE menurut Gulland (1991), King (1995), dan Spare and Vennema (1998), yakni:

$$
U=C_{i} / f_{i}
$$

menjadi

$$
U_{i j}=C_{i j} / f_{i j}
$$

dimana:

$U_{i j} \quad$ : Jumlah hasil tangkapan per unit upaya penangkapan (CPUE) oleh jenis alat penangkap ikan (API) ke- $i$ (kg/trip) pada bulan ke-j tiap sub DPI

$C_{i j} \quad$ : Hasil tangkapan ikan $(\mathrm{kg})$ oleh jenis API ke-i pada bulan ke-j tiap sub DPI

$f_{i j} \quad$ : Upaya penangkapan (trip) oleh jenis API ke-i pada bulan ke- $j$ tiap sub DPI

2) Selanjutnya menghitung CPUE rata-rata bulanan dalam setahun sebagai berikut: 


$$
\bar{U}=\frac{1}{n} \sum_{i=1}^{n} U_{i} \text { atau } \overline{C P U E}=\frac{1}{n} \sum_{i=1}^{n} C P U E_{i}
$$

Dimana:

$\overline{C P U E}$ : CPUE rata-rata bulanan dalam setahun di sub DPI bersangkutan

$C P U E_{i}$ : CPUE tiap bulan di sub DPI bersangkutan $n \quad$ : jumlah bulan operasi penangkapan dalam setahun di sub DPI bersangkutan

3) Menghitung indeks musim (IM) penangkapan ikan pelagis bulanan masing-masing jenis API di setiap sub DPI dengan model matematis:

$$
\mathrm{IM}=\left(C P U E_{i j} / \overline{C P U E}\right) * 100 \%
$$

dimana:

$C P U E_{i j} \quad$ : CPUE API ke-i pada bulan ke-j tiap sub DPI

\section{$\overline{C P U E}$ : CPUE rata-rata bulanan oleh API bersangkutan tiap sub DPI}

Kriteria pengambilan keputusan untuk penentuan musim penangkapan ikan adalah bila nilai IM sama dengan atau lebih dari $100 \%$ ( $\geq$ $100 \%$ ), dapat dikatakan sebagai musim penangkapan sedangkan bila kurang dari 100\% (< $100 \%$ ) maka bukan merupakan musim penangkapan (Syahrir dkk, 2010). Apabila IM sama dengan 100\% $(\mathrm{IM}=100 \%)$ atau sama dengan rata-rata bulanan, dapat dikatakan musim normal atau berimbang (Kekenusa, 2006).

\section{HASIL DAN PEMBAHASAN}

\section{Batas Dan Luas Daerah Penangkapan Ikan, Serta Jalur-Jalur Penangkapan Ikan}

Undang-Undang Nomor 23 Tahun 2014

Pasal 27 ayat 3 menetapkan bahwa batas pengelolaan wilayah laut antar daerah provinsi adalah paling jauh 12 mil laut yang diukur dari garis pantai ke arah laut lepas dari masing-masing provinsi. Pada ayat 4 dikatakan apabila wilayah laut antara dua daerah provinsi yang saling berbatasan kurang dari 24 mil laut maka pembagian kewenangan pengelolaan lautnya dibagi sama jarak atau diukur sesuai dengan prinsip garis tengah (median line) (Khomsin $d k k$, 2016). Ketentuan ini kemudian ditindaklanjuti berdasarkan Peraturan Menteri Dalam Negeri Republik Indonesia Nomor 141 Tahun 2017, Peraturan Daerah Kota Ambon Nomor 2 Tahun 2006 (BPS Kota Ambon, 2017) dan Nomor 17 Tahun 2008, untuk memetakan batas wilayah perairan di Kota Ambon. Penampakan wilayah pemerintahan Kota Ambon, termasuk wilayah bagi hasil kelautan yang berada pada batas wilayah 4 (empat) mil laut diukur dari garis pantai ke arah laut lepas dan/atau ke arah perairan kepulauan dan sesuai dengan prinsip garis tengah dari daerah berbatasan yang kurang dari 4 (empat) mil laut. Pemetaan dan perhitungan luas daerah penangkapan ikan di perairan Kota Ambon dan sekitarnya, dibuat berdasarkan Peraturan Menteri Kelautan dan Perikanan Republik Indonesia Nomor 71 Tahun 2016 tentang Jalur Penangkapan Ikan dan Penempatan Alat Penangkapan Ikan Di Wilayah Pengelolaan Perikanan Negara Republik Indonesia dan diperlihatkan pada Gambar 1.

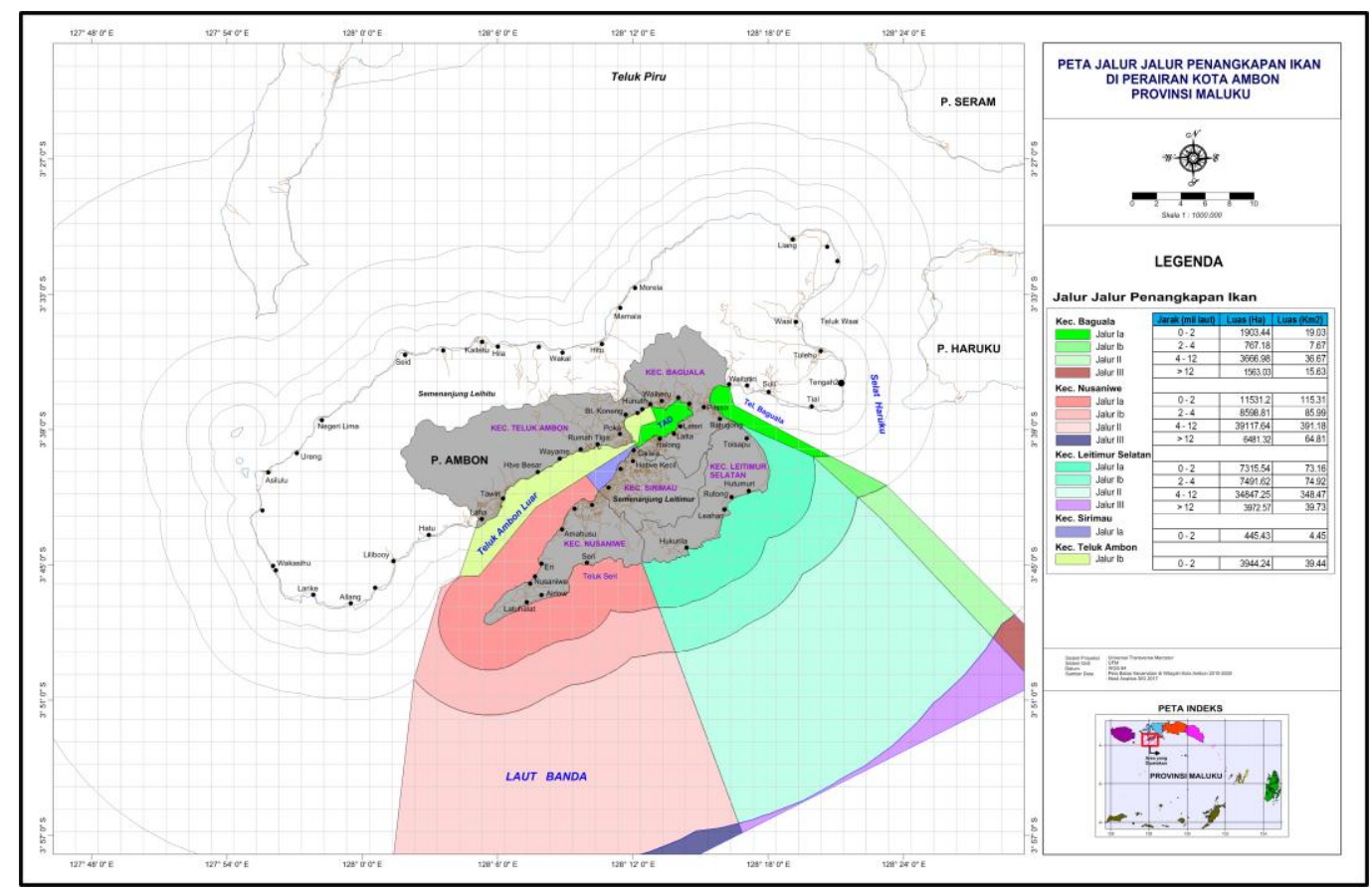

Gambar 1. Peta daerah penangkapan dan jalur-jalur penangkapan ikan di perairan Kota Ambon dan sekitarnya 
Perairan yang dimanfaatkan sebagai daerah penangkapan ikan oleh para nelayan Kota Ambon mencakup wilayah perairan pada jalur penangkapan "IA" (0-2 mil laut) dan jalur penangkapan ikan "IB (2-4 mil laut) yang adalah perairan yang dikelola oleh Pemerintah Kota Ambon, bahkan hingga jalur penangkapan ikan II (4-12 mil laut) yang merupakan perairan yang dikelola oleh Pemerintah Provinsi Maluku dan jalur penangkapan ikan III (> 12 mil laut) yang dikelola oleh Pemerintah Pusat. Luas wilayah perairan yang berbatasan langsung dengan wilayah Pemerintahan Kota Ambon dan diakses sebagai daerah penangkapan ikan oleh nelayannelayan Kota Ambon adalah 1.316,46 km², yakni 419,97 $\mathrm{km}^{2}$ pada wilayah kelola Kota Ambon dan $776,32 \mathrm{~km}^{2}$ pada wilayah kelola Provinsi Maluku, serta $39,73 \mathrm{~km}^{2}$ pada wilayah pengelolaan Pemerintah Pusat. Rincian luas jalur-jalur penangkapan ikan yang diperhitungkan berdasarkan undang-undang dan peraturan di atas dengan pendekatan Sistem Informasi Geografis (SIG), ditampilkan pada Tabel 1.

Tabel 1. Luas wilayah perairan yang dimanfaatkan oleh nelayan Kota Ambon sebagai daerah penangkapan ikan

\begin{tabular}{|c|c|c|c|c|c|c|}
\hline \multirow{2}{*}{ No. } & \multirow{2}{*}{ Kecamatan } & \multicolumn{4}{|c|}{ Luas Jalur-Jalur Penangkapan Ikan $\left(\mathrm{km}^{2}\right)$} & \multirow{2}{*}{$\begin{array}{c}\text { Jumlah } \\
\left(\mathrm{km}^{2}\right)\end{array}$} \\
\hline & & IA & IB & II & III & \\
\hline 1. & Nusaniwe & 115,31 & 85,99 & 391,18 & 64,81 & 657,29 \\
\hline 2. & Sirimau & 4,45 & - & - & - & 4,45 \\
\hline 3. & Teluk Ambon & 39,44 & - & - & - & 39,44 \\
\hline 4. & Teluk Ambon Baguala & 19,03 & 7,67 & 36,67 & 15,63 & 79,00 \\
\hline 5. & Leitimur Selatan & 73,16 & 74,92 & 348,47 & 39,73 & 536,28 \\
\hline & Total $\left(\mathrm{km}^{2}\right)$ & 251,39 & 168,58 & 776,32 & 120,17 & $1.316,46$ \\
\hline
\end{tabular}

Keterangan:

Jalur "IA" (0-2 mil laut) dan Jalur IB (2-4 mil laut) adalah wilayah pengelolaan Kota Ambon

Jalur II (4-12 mil laut) adalah wilayah pengelolaan Provinsi Maluku

Jalur III (> 12 mil laut) adalah Wilayah pengelolaan Pemerintah Pusat

Luas daerah penangkapan ikan 0-2 mil laut (jalur penangkapan ikan IA) perairan Kota Ambon adalah $251,39 \mathrm{~km}^{2}$ dan 2-4 mil laut (jalur penangkapan ikan IB) adalah seluas $168,58 \mathrm{~km}^{2}$, serta daerah penangkapan ikan yang merupakan wilayah kelola Provinsi Maluku yang juga diakses oleh nelayan Kota Ambon yang memiliki kapal/perahu bermesin penggerak pada wilayah perairan 4-12 mil laut (jalur penangkapan ikan II) adalah seluas $776,32 \mathrm{~km}^{2}$, bahkan hingga wilayah perairan $>12$ mil laut (jalur penangkapan ikan III). Penggunaan teknologi penangkapan ikan oleh para nelayan Kota Ambon, mengindikasikan bahwa mereka lebih dominan memanfaatkan "jalur penangkapan ikan Ia" dan "jalur penangkapan ikan Ib" sebagai daerah penangkapan ikan, hanya beberapa diantaranya yang dapat mengakses hingga daerah penangkapan ikan di "jalur penangkapan ikan II" dan "jalur penangkapan ikan "III" pada operasi penangkapan dengan pole and line dan troll line untuk menangkap ikan pelagis besar. Kondisi ini menyatakan bahwa para nelayan Kota Ambon memanfaatkan wilayah perairan laut sekitar Kota Ambon seluas 1.316,46 km ${ }^{2}$ atau bahkan lebih luas hingga ke perairan Laut Seram sebagai daerah penangkapan ikan pelagis.

\section{Musim Penangkapan Ikan Pelagis Kota Ambon}

Perairan yang dijadikan sebagai daerah penangkapan ikan (DPI) pelagis oleh para nelayan Kota Ambon yaitu perairan Teluk Ambon Dalam (TAD), Teluk Ambon Luar (TAL), Teluk Baguala (TB), Selatan Ambon (SA), Laut Banda (LB), dan bahkan hingga perairan Laut Seram (LS). Operasi penangkapan ikan pelagis oleh nelayan-nelayan yang berpangkalan (fishing base) di Kota Ambon dengan menggunakan 7 (tujuh) jenis API pelagis, ternyata sangat bervariasi sesuai dengan DPI dan musim penangkapan ikan. Musim penangkapan ikan yang dialami di DPI Kota Ambon dan sekitarnya, diketahui sebanyak 4 (empat) musim, yaitu musim Barat terjadi pada bulan Desember hingga Pebruari, musim pancaroba I (peralihan dari Barat ke Timur) terjadi pada bulan Maret hingga Mei, musim Timur terjadi pada bulan Juni hingga Agustus, dan musim pancaroba II (peralihan dari Timur ke Barat) terjadi pada bulan September hingga Nopember.

Nelayan-nelayan Kota Ambon memilih DPI berdasarkan jenis API yang digunakan, pangkalan nelayan (fishing base), dan musim penangkapan ikan, selain kondisi fisik DPI yang memungkinkan untuk melaut. Pukat pantai (beach seine) hanya dioperasikan di DPI Teluk Ambon Dalam dan bagan/jaring angkat (lift net) hanya dioperasikan di DPI Teluk Baguala. Jenis API pelagis lainnya akan memilih DPI yang berpindah-pindah (bergeser) sesuai dengan musim penangkapan ikan pelagis. Penentuan musim penangkapan ikan pelagis berdasarkan Indeks Musim (IM) penangkapan dapat dijadikan sebagai acuan pada operasi penangkapan ikan. Musim penangkapan ikan pelagis di Kota Ambon, ditampilkan pada Tabel 2.

Para nelayan yang berpangkalan (fishing base) di desa Waiheru, Hunut, Poka, dan Lateri mengoperasikan pukat pantai (beach seine) sepanjang tahun untuk menangkap ikan pelagis kecil di DPI Teluk Ambon Dalam. Puncak musim 
penangkapan ikan pelagis (musim ikan) di DPI Teluk Ambon Dalam terjadi pada musim Barat hingga awal musim pancaroba I, sementara hasil tangkapan akan turun (sedikit) pada akhir musim Timur hingga awal musim pancaroba II.

Pukat cincin (purse seine) dioperasikan di DPI Teluk Ambon Luar, Selatan Ambon, dan bahkan hingga Laut Seram (wilayah Kabupaten Seram Bagian Barat/SBB) khususnya oleh nelayan-nelayan yang berpangkalan (fishing base) di Hatiwe Besar, Latuhalat, dan Seri. Para nelayan yang berpangkalan (fishing base) di Laha, Latta, dan Kamiri, memilih DPI Teluk Ambon Luar. Puncak penangkapan ikan pelagis di DPI Teluk Ambon Luar dan Laut Seram terjadi pada akhir musim pancaroba II hingga awal musim pancaroba I, serta di DPI Selatan Ambon pada akhir musim Barat hingga musim pancaroba I.

Tabel 2. Sub Daerah penangkapan ikan (DPI) dan musim penangkapan ikan pelagis dari 7 (tujuh) alat penangkap ikan (API) di Kota Ambon dan sekitarnya

\begin{tabular}{|c|c|c|c|c|c|c|c|c|c|c|c|c|c|c|}
\hline \multirow{2}{*}{ No } & \multirow{2}{*}{$\begin{array}{c}\text { Alat } \\
\text { Penangkap } \\
\text { Ikan }\end{array}$} & \multirow{2}{*}{$\begin{array}{l}\text { Sub } \\
\text { DPI }\end{array}$} & \multicolumn{12}{|c|}{ Indeks Musim (IM) Penangkapan (\%) Tiap Bulan } \\
\hline & & & 1 & 2 & 3 & 4 & 5 & 6 & 7 & 8 & 9 & 10 & 11 & 12 \\
\hline 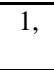 & $\begin{array}{l}\text { Pukat Pantai } \\
\text { (beach seine) }\end{array}$ & TAD & 130,3 & 130,3 & 130,3 & 997,1 & 95,5 & 95,5 & $9 \overline{95,5}$ & 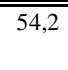 & 55,8 & 58,3 & 12121,0 & 136,3 \\
\hline \multirow[t]{3}{*}{2,} & \multirow{3}{*}{$\begin{array}{l}\text { Pukat Cincin } \\
\text { (purse seine) }\end{array}$} & TAL & 108,9 & 113,9 & 161,6 & 122,6 & 89,1 & 79,7 & 39,3 & 74,0 & 97,9 & 143,2 & 100,7 & 77,0 \\
\hline & & SA & 108,1 & 189,7 & 180,3 & 225,4 & 130,9 & 92,0 & 91,3 & 69,5 & 56,1 & 39,8 & 9,4 & 7,4 \\
\hline & & $\mathrm{LS}$ & 107,6 & 132,1 & 136,0 & 100,1 & 67,3 & 79,5 & 64,6 & 64,7 & 98,7 & 111,8 & 116,8 & 120,7 \\
\hline \multirow[t]{4}{*}{3,} & \multirow{4}{*}{$\begin{array}{l}\text { Jaring Insang } \\
\text { (gill net) }\end{array}$} & TB & 132,6 & 132,6 & 105,2 & 94,9 & 56,8 & 40,1 & 40,1 & 94,9 & 105,2 & 132,6 & 132,6 & 132,6 \\
\hline & & TAD & 124,5 & 124,5 & 102,4 & 86,2 & 81,5 & 68,0 & 68,0 & 68,3 & 100,6 & 124,8 & 125,4 & 125,4 \\
\hline & & TAL & 110,1 & 110,1 & 110,1 & 110,1 & 101,8 & 85,8 & 79,3 & 84,3 & 97,4 & 116,7 & 97,4 & 97,4 \\
\hline & & SA & 116,0 & 114,1 & 100,6 & 85,6 & 69,8 & 69,6 & 69,8 & 85,5 & 104,3 & 126,2 & 131,5 & 127,0 \\
\hline 4 & $\begin{array}{l}\text { Bagan (lift } \\
\text { net) }\end{array}$ & TB & 68,0 & 79,8 & 68,0 & - & - & - & - & - & 118,2 & 147,8 & 118,2 & 59,1 \\
\hline \multirow[t]{2}{*}{5} & \multirow{2}{*}{$\begin{array}{l}\text { Huhate (pole } \\
\text { and line) }\end{array}$} & SA & 78,1 & 65,1 & 52,1 & 52,1 & 52,1 & 52,1 & 52,1 & 65,1 & 65,1 & 104,2 & 117,2 & 130,2 \\
\hline & & LS & 78,1 & 65,1 & 52,1 & 52,1 & 52,1 & 52,1 & 52,1 & 65,1 & 65,1 & 104,2 & 117,2 & 130,2 \\
\hline \multirow[t]{4}{*}{6} & \multirow{4}{*}{$\begin{array}{l}\text { Pancing } \\
\text { Tonda (troll } \\
\text { line) }\end{array}$} & TAL & 55,6 & 112,7 & 56,6 & 75,9 & 31,2 & - & - & - & 127,2 & 132,3 & 133,6 & 51,5 \\
\hline & & SA & 114,5 & 119,5 & 101,9 & 86,2 & 57,7 & 58,0 & 58,4 & 80,2 & 94,1 & 117,5 & 117,5 & 117,5 \\
\hline & & LB & 51,1 & 110,2 & 159,9 & 111,9 & 31,1 & 34,5 & 39,7 & 39,7 & 67,3 & 86,3 & 86,3 & 86,3 \\
\hline & & LS & 109,9 & 99,4 & 143,4 & 90,5 & 48,1 & 64,9 & 90,5 & 153,3 & 94,7 & - & - & - \\
\hline \multirow[t]{4}{*}{7} & \multirow{4}{*}{$\begin{array}{l}\text { Pancing } \\
\text { Tangan (hand } \\
\text { line) }\end{array}$} & TAD & 105,8 & 98,3 & 97,0 & 90,7 & 88,2 & 85,7 & 93,2 & 98,3 & 98,3 & 113,4 & 113,4 & 118,4 \\
\hline & & TAL & 127,0 & 127,0 & 127,0 & 127,0 & 63,5 & 63,5 & 63,5 & 63,5 & 63,5 & 127,0 & 127,0 & 127,0 \\
\hline & & TB & 62,8 & 109,9 & 120,4 & 89,0 & 71,2 & 26,2 & 20,9 & 79,5 & 53,4 & 113,0 & 68,0 & 32,4 \\
\hline & & SA & 102,6 & 134,2 & 148,1 & 32,3 & 27,4 & 25,8 & 25,8 & 27,4 & 27,4 & 125,2 & 165,8 & 169,7 \\
\hline
\end{tabular}

Sumber: Data primer (diolah)

Keterangan: (-) tidak ada operasi penangkapan ikan pelagis

Nelayan-nelayan Kota Ambon mengoperasi kan jaring insang (gill net) untuk menangkap ikan pelagis di DPI Teluk Baguala, Teluk Ambon Dalam, Teluk Ambon Luar, dan Selatan Ambon. Operasi penangkapan ikan pelagis dengan jaring insang (gill $n e t)$, relatif dapat dilakukan sepanjang tahun. Puncak penangkapan di DPI Teluk Baguala, Teluk Ambon Dalam, dan Selatan Ambon. terjadi pada musim pancaroba II hingga musim pancarona I, serta di Teluk Ambon Luar terjadi pada akhir musim Barat hingga awal musim pancaroba I. Bagan/jaring angkat (lift net) dioperasikan oleh para nelayan Kota Ambon untuk menangkap ikan pelagis dengan menempatkannya di DPI Teluk Baguala. Sepanjang tahun. API ini hanya dioperasikan dari bulan September hingga Maret karena bulan April hingga Agustus perairan Teluk Baguala berombak dan bergelombang. Penangkapan ikan pelagis besar oleh para nelayan Kota Ambon dengan huhate (pole and line) di DPI Selatan Ambon dan Laut Seram. Nelayan-nelayan ini dapat melakukan operasi penangkapan ikan sepanjang tahun, dengan puncak penangkapan terjadi pada musim pancaroba II hingga awal musim Barat. Jenis-jenis ikan pelagis besar ditangkap oleh para nelayan Kota Ambon dengan pancing tonda (troll line). Puncak penangkapan dengan pancing tonda (troll line) di DPI Teluk Ambon Luar terjadi pada musim pancaroba II, di DPI Selatan Ambon pada musim Barat hingga awal musim pancaroba I, di DPI Laut Banda pada musim pancaroba I, dan di DPI Laut Seram pada akhir musim Barat dan musim Timur. Hasil tangkapan kurang (paceklik) di DPI Teluk Ambon Luar terjadi pada musim pancaroba I dan musim Timur. API ini tidak dapat beroperasi di DPI Selatan Ambon dan Laut Banda pada musim Timur, dan di DPI Laut Seram pada musim Barat karena kondisi fisik DPI tidak memungkinkan untuk mengoperasikan API akibat kecepatan angin gelombang laut yang tinggi. Nelayan yang mengoperasikan pancing tangan (hand line) cenderung memilih DPI yang dekat dengan pangkalannya (fishing base) karena menggunakan kapal/perahu tanpa motor. Puncak penangkapan ikan dengan pancing tangan (hand line) umumnya pada akhir musim Barat hingga awal musim pancaroba I.

Aktifitas operasi penangkapan ikan pelagis di DPI, dipengaruhi oleh iklim dan cuaca yang terjadi di Kota Ambon. Keadaan iklim dan cuaca di Kota Ambon seperti diperlihatkan pada Gambar 2, menunjukkan bahwa curah hujan, jumlah hari hujan, 
kecepatan angin, dan tinggi gelombang di laut mulai meningkat pada bulan Maret hingga Mei (musim Pancaroba I) kemudian tinggi pada bulan Juni dan Juli. Kondisi ini sangat tidak menguntungkan bagi nelayan untuk melakukan aktifitas operasi penangkapan ikan di DPI. Keadaan sebaliknya terjadi pada bulan September hingga Pebruari (awal musim Pancaroba II hingga akhir musim Barat) yang cenderung berkurang dan rendah sehingga menguntungkan para nelayan di Kota Ambon untuk melakukan kegiatan operasi penangkapan ikan pelagis.

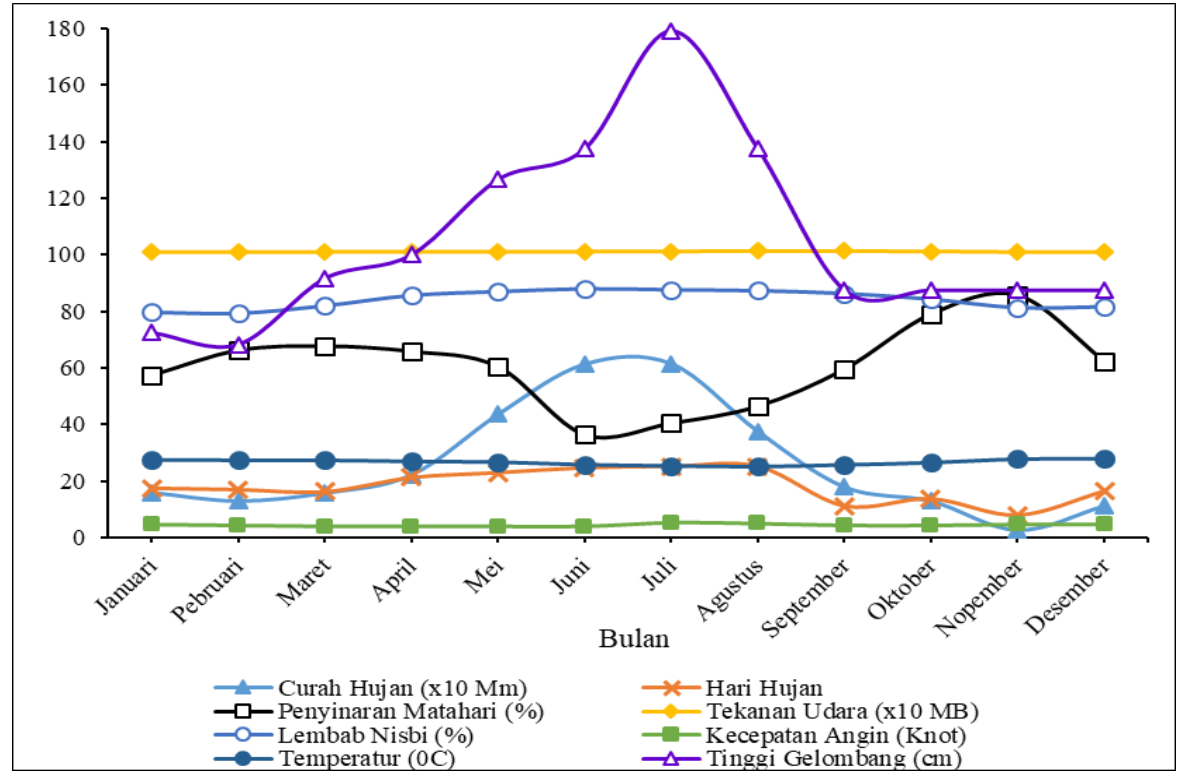

Gambar 2. Keadaan beberapa parameter iklim dan cuaca rata-rata di Kota Ambon dari bulan Januari hingga Desember

Sumber: Badan Pusat Statistik Kota Ambon (2008-2016) BMKG Stasiun Meteorologi Pattimura Ambon (2017-2018)

\section{KESIMPULAN}

Penelitian ini menyimpulkan beberapa hal sesuai dengan tujuannya, sebagai berikut:

1) Pemetaan daerah penangkapan ikan (DPI) pelagis Kota Ambon dan sekitarnya menghasilkan luas perairan pada batas $0-4$ mil laut yang merupakan wilayah kelola Kota Ambon seluas $419.97 \mathrm{~km}^{2}$. Perairan yang merupakan wilayah kelola Provinsi Maluku yakni pada batas 4-12 mil laut seluas $776.32 \mathrm{~km}^{2}$ dan wilayah kelola pemerintah pusat pada batas $>12$ mil laut adalah seluas $120.17 \mathrm{~km}^{2}$.

2) Pada umumnya puncak musim penangkapan ikan pelagis di DPI Kota Ambon terjadi pada musim pancaroba II hingga musim Barat dan paceklik pada musim Timur, dan dipengaruhi oleh iklim dan cuaca.

\section{SARAN}

Penelitian-penelitian untuk mengungkap status daerah penangkapan ikan (fishing ground) perlu dikembangkan dan diintensifkan, serta dilakukan di berbagai perairan agar pemanfaatan sumberdaya perikanan melalui aktifitas penangkapan ikan dapat dilakukan secara baik dan tepat.

\section{UCAPAN TERIMA KASIH}

Penulis menyampaikan terima kasih banyak kepada para enumerator, saudara W. Waileruny, dan saudara J.J. Wattimury yang dengan sukacita telah membantu terlaksananya penelitian ini.

\section{DAFTAR PUSTAKA}

Badan Pusat Statistik Kota Ambon, 2009-2017. Kota Ambon Dalam Angka.

Badan Meteorologi Klimatologi Dan Geofisika Stasiun Meteorologi Pattimura Ambon, 20172018. Prakiraan Cuaca Wilayah Pelayanan.

Departemen Kelautan dan Perikanan, 2004. Ensiklopedi Perikanan. Direktorat Kelembagaan Internasional. Direktur Jenderal Peningkatan Kapasitas Kelembagaan dan Pemasaran (Ditjen PK2P). Jakarta.

Departemen Kelautan dan Perikanan, 2006. Panduan Pengambilan Data Dengan Metode Rapid Rural Appraisal (RRA) dan Participatory Rural Appraisal (PRA). Program Rehabilitasi dan Pemulihan Cadangan Sumberdaya Alam. Satker Rehabilitasi dan Pengelolaan Terumbu Karang (COREMAP II) Tahun 2006. Dirjen KP3K. DKP. Jakarta. 
Dinas Kelautan dan Perikanan Provinsi Maluku. Buku Tahunan Statistik Perikanan Provinsi Maluku Tahun 2005 - 2016.

Fauzi A., dan Suzy Anna, 2005. Pemodelan Sumber Daya Perikanan dan Kelautan Untuk Analisis Kebijakan. Penerbit PT. Gramedia Pustaka Utama. Jakarta.

Fauzi A., 2010. Ekonomi Perikanan. Teori. Kebijakan. dan Pengelolaan. Penerbit Pt. Gramedia Pustaka Utama. Anggota IKAPI. Jakarta.

Freudenberger K. S., 2008. Rapid Rural Appraisal (RRA) and Participatory Rural Appraisal (PRA). A Manual for CRS Field Workers and Partners. 228 W. Lexinton Street. Baltimore. Maryland 21201-3443.

Gulland. J. A., 1991. Fish Stock Asessment. A Manual of Basic Methods. Marine Resources Service. Fishery Resources and Enviroment Division. FAO-UN. Rome. Italy. John Wiley and Sons.

Harjanti R., Pramonowibowo, dan Trisnani Dwi Hapsari, 2012. Analisis Musim Penangkapan dan Tingkat Pemanfaatan Ikan Layur (Trichiurus sp) di Perairan Pelabuhan Ratu. Sukabumi. Jawa Barat. Journal of Fisheries Resources Utilization Management and Technology. Volume 1. Nomor 1. Hlm 55-56.

Kawaguchi S., S. Nicol, K. Taki, and M. Naganobu, 2006. Fishing Ground Selection In The Antartic Krill Fishery: Trends in Patterns Across Years. Seasons and Nations. CCAMLR Science. Vol. 13 (2006). P 117-141.

Kekenusa J. S., 2006. Analisis Penentuan Musim Penangkapan Ikan Cakalang (Katsuwonus pelamis) Di Perairan Sekitar Bitung Sulawesi Utara. Jurnal Protein Volume 13 No. 1.

Khomsin dan Rainhard S. Simatupang, 2016. Penentuan Batas Pengelolaan Laut Daerah Antara Provinsi Jawa Timur Dan Provinsi Bali Berdasarkan Undang-Undang Republik Indonesia Nomor 23 Tahun 2014. GEOID Vol. 12 No. 1. (hal 83-88)

King M., 1995. Fisheries Biology. Assesment and Management. Fishing News Book. A division of Blackwell Science Ltd.

Peraturan Daerah Kota Ambon Nomor 17 Tahun 2008 tentang Pedoman Umum Penetapan Batas Wilayah Negeri Di Kota Ambon

Peraturan Menteri Dalam Negeri Republik Indonesia Nomor 141 Tahun 2017 tentang Penegasan Batas Daerah.

Peraturan Menteri Kelautan dan Perikanan Republik Indonesia Nomor: 4/PERMEN-KP/2015 tentang Larangan Penangkapan Ikan Di Wilayah Pengelolaan Perikanan Negara Republik Indonesia 714.

Peraturan Menteri Kelautan dan Perikanan Republik Indonesia Nomor: 71/PERMEN-KP/2016 tentang Jalur Penangkapan Ikan dan Penempatan Alat Penangkapan Ikan Di Wilayah
Pengelolaan Perikanan Negara Republik Indonesia.

Sparre P., and S. C. Venema, 1998. Introduction to Tropical Fish Stock Assesment Part 1-Manual FAO Fisheries Technical Paper. FAO Rome.

Syahrir M., R., Mulyono S. Baskoro, Darmawan, Ernani Lubis, dan Eko Sri Wiyono, 2010. Pola Musim Penangkapan Ikan Pelagis Di Perairan Teluk Apar. Jurnal Ilmu Perikanan Tropis Vol. 13 No. 1.

Undang-Undang Republik Indonesia Nomor 45 Tahun 2009 tentang Perubahan Atas UndangUndang Nomor 31 Tahun 2004 tentang Perikanan.

Undang-Undang Republik Indonesia Nomor 23 Tahun 2014 tentang Pemerintahan Daerah.

Widodo J. dan Suadi, 2006. Pengelolaan Sumberdaya Perikanan Laut. Penerbit Gadjah Mada University Press. P.O.Box 14, Bulaksumur, Yogyakarta 